\title{
THE IMPACT OF ONLINE PEER FEEDBACK ON EFL STUDENTS' WRITING AT TERTIARY LEVEL
}

\author{
Achmad Yudi Wahyudin \\ Faculty of Arts and Education,Universitas Teknokrat Indonesia, \\ Zainal Abidin Pagar Alam Street 9-11, \\ Bandar Lampung, Indonesia \\ Email: achmad.yudi@teknokrat.ac.id
}

\begin{abstract}
The need for supporting the practice of teaching English as Foreign Language (EFL) writing at tertiary level has been the major concern for researchers and practitioners. Peer feedback has received much attention since its effectiveness in enhancing students' writing ability. However, English teachers have often encountered time constraints and large class during the writing process. Currently, Facebook becomes one of the most popular social network site (SNS) in Indonesia and has been a very potential platform to help English teachers to facilitate learning. This paper attempts to confirm whether the use of Facebook as a medium of peer feedback outside the classroom can improve EFL Students' Writing ability. The subjects were 81 undergraduate students studying Essay Writing which is a compulsory subject in English Department in Universitas Teknokrat Indonesia. The subjects then were randomly assigned into experimental group and control group. The experiment lasted for eight weeks started with pre-test in the beginning and ended with a post-test in the last meeting. During the treatment, the teacher applied planning, drafting, revising and editing stages and online learning with Facebook as the medium to facilitate the students' peer feedback. The result shows online peer feedback with Facebook may be used as an effective instructional media. It could help students improve their writing ability as well as critical thinking.
\end{abstract}

Keywords: Facebook, Writing Ability, Tertiary Level, Online Peer Feedback

\section{INTRODUCTION}

Writing becomes a very important skill

for EFL undergraduate students in

Indonesia since the success of the students

highly depend on their ability to accomplish various assignments in written form. The

practice of teaching writing for

undergraduate level is often concerned with

various genres (See Aunurrahman, Hamied,

\& Emilia, 2017) and conducted recursively

BAHTERA : Jurnal Pendidikan Bahasa dan Sastra, Volume Januari 2018 
which the students are given the opportunity to edit and revise his or her work so as to reorganize ideas and to discover and remake new ideas (Kroll, 2001).

However, The English teachers have often encountered large class in which some of the students are not engaged in the learning process (Al-Badwawi, 2011: 168) and have minimum opportunity to have revision from teacher and peer (Choo, 2001; and Razak \& Saeed, 2014). In addition limited time has been the problem inevitably faced by the English teachers.

Therefore, innovative and interesting instructional techniques are needed to provide the students more flexible time and to support them to actively take part in writing process as to enhance their writing ability.

At tertiary level, peer feedback has been often utilized to support the writing process (Rollinson, 2005). Peer feedback in this paper is seen as the reflective process in which the students give comment, criticism, and suggestion towards the other students' work (Falchikov 2001). To support the engagement of students in writing, peer feedback process is nowadays often done in online environment since face-to-face peer feedback is considered time-consuming (See Choi, 2014).

Numerous studies have been reported to confirm the benefit of peer feedback in writing process (Al-Ghazali, 2015; Yang \& Meng, 2013; Guasch, Espasa, Alvarez \& Kischner, 2013; Choi, 2014; Razak \& Saeed, 2014; Klucevsek, 2016). However, little has been known to confirm the effectiveness of social networks' inclusion in facilitating peer feedback to enhance the students' writing ability.

Currently, social networks have been more popular throughout the world since their multidimensional uses including in language learning and teaching. 
Numerous studies on Facebook's inclusion

in L2 education environments have reported positive influences on student motivation, engagement, and attitudes (Low \& Warawudhi, 2016; Kabilan, Ahmad, \& Abidin, 2010; Yunus \& Salehi, 2012; Budiardi \& Anggraeni, 2013; Suthiwartnarueput \& Wasanasomsithi, 2012).

Even though the previous studies have concerned the use of Facebook in improving the EFL students' writing ability, there is no further confirmation whether or not online peer feedback with Facebook can affect positively students' writing ability. Therefore, the present study attempted to investigate the impact of online peer feedback on the EFL students writing ability.

\section{METHOD}

The present study employed an experimental design in which 81 undergraduate students studying Essay Writing were randomly assigned into experimental group and control group. The participants' age in this study ranged from 20-23 years old and they did not take any English course outside of the class.

The experiment lasted for eight weeks started with pre-test in the beginning of the meeting and ended with a post-test in the last meeting. Those tests were concerned with argumentative writing consisted of thesis, arguments, reiteration or recommendation (Coffin, 2004; Martin, 2006) since this genre is suitable for undergraduate students (See Aunurrahman, Hamied, \& Emilia, 2017).

During the treatment, the teacher combined the process writing in which the teacher applied planning, drafting, revising 
and editing stages (Kroll, 2001) and online learning with Facebook as the medium to facilitate the students' peer feedback towards the argumentative essay they have composed. The students' work was analysed by the scoring criteria adapted from Hughes (2003). The criteria ranged from 0 to 100 where content, organization, language use, vocabulary, and mechanics became the aspects being measured. The students' work is graded by multiple rater to ensure the inter-rater reliability of the test.

Several statistical analyses such as normality test, homogeneity test were done through SPSS (ver.15). In addition, the following hypotheses were also tested using similar software.

$\mathrm{H}_{0}=$ There is no significant difference of writing ability between experimental group and control group
$\mathrm{H}_{1}=$ There is a significant difference of writing ability between experimental group and control group.

\section{RESULTS \& DISCUSSION}

The present study aims at confirming whether online peer feedback with Facebook impact positively on the EFL students' writing ability. The subjects in experimental and control group were assigned to write an argumentative essay in the pre-test and post test. The test lasted in 100 minutes where the students were not allowed to consult a dictionary and internet source. The impact of online peer feedback can be seen in the difference of writing ability between the experimental and control group.

Table 3.1: The comparison between experimental and control group in pre-test.

\begin{tabular}{|l|l|c|c|l|}
\hline Group & $\begin{array}{l}\text { Mea } \\
\mathrm{n}\end{array}$ & $\begin{array}{l}\text { Minim } \\
\text { um }\end{array}$ & $\begin{array}{l}\text { Maxim } \\
\text { um }\end{array}$ & SD \\
\hline $\begin{array}{l}\text { Experime } \\
\text { ntal }\end{array}$ & $\begin{array}{l}76.9 \\
7\end{array}$ & 43 & 86 & $\begin{array}{l}10.0 \\
6\end{array}$ \\
\hline Control & 75.2 & 58 & 81 & 5.82 \\
\hline
\end{tabular}




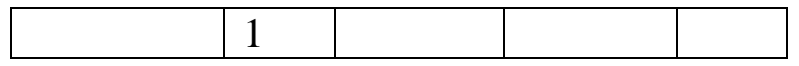

Table 3.1 suggested that the students treated in experimental group and the students treated in control group have relatively equal ability. It can be seen that the mean score of experimental group is 76.97 while the mean of control group is 75.21. After studying for almost a semester, the post test was administered to both groups and the result can be seen in the following table.

Table 3.2: The comparison between experimental and control group in post test.

\begin{tabular}{lcccc}
\hline Group & Mean & $\begin{array}{l}\text { Minimu } \\
\mathbf{m}\end{array}$ & $\begin{array}{l}\text { Maxim } \\
\text { um }\end{array}$ & SD \\
\hline $\begin{array}{l}\text { Experime } \\
\text { ntal }\end{array}$ & 82.56 & 64 & 87 & 4.31 \\
Control & 79.92 & 65 & 84 & 3.47 \\
\hline
\end{tabular}

Table 3.2 pointed out that the students treated in experimental class outperformed the students treated in control group. It can be seen that the mean score of experimental group is 82.56 while the mean of control group is 79.92. Since the mean score between the two groups was slightly different, this result might be an indication of the impact of online peer feedback on the students' writing.

Furthermore, the formulated hypotheses were tested to investigate whether there is any significant difference of writing ability between experimental and control group. The result of hypothesis testing can be seen in the following table.

Table 3.3: The result of independent $t-$ test.

\begin{tabular}{llcccc}
\hline Writing & $\begin{array}{c}\text { Mean } \\
\text { difference }\end{array}$ & $\mathbf{t}$ & df & $\begin{array}{c}\text { Sig. } \\
(\mathbf{2 -} \\
\text { tailed) }\end{array}$ \\
\hline & $\begin{array}{l}\text { equal } \\
\text { variance } \\
\text { assumed }\end{array}$ & 2.63 & 3.03 & 79 & .003 \\
& $\begin{array}{l}\text { equal } \\
\text { variance } \\
\text { not } \\
\text { assumed }\end{array}$ & 2.63 & 3.01 & 72 & .004 \\
\hline
\end{tabular}

Table 3.3 pointed out that the experimental and control group are different significantly at $.003(\mathrm{t}=3.03)$ in which it is below $\alpha(.05)$. Also, it is noted that the mean difference between the two groups is 2.63 with the degree of freedom 
79. Based on this result, the null $\left(\mathrm{H}_{0}\right)$ hypothesis was rejected and in other words, there is a significant difference of writing ability between the experimental and control group.

Hence, the finding indicates that the use of online peer feedback with Facebook give more positive impact to the students' writing ability than any teaching method used in control group. The finding of the present study might support the several studies conducted by Razak and Saeed, (2014), Guasch et al, (2014) and Klucevsek (2016).

Peer feedback outside the classroom space was given to provide an opportunity for students to practice their writing skill, as well as improve their analytical and error correction skill. An online English-learning group in Facebook provided an opportunity for students to collaboratively revise their writing in a non-classroom context (Razak and Saeed, 2014). In this study, the majority of peer feedback comments reflect the content, language use, idea organization, and mechanics of the writing. This finding somehow does not correspond to the finding of the study conducted Razak and Saeed (2014) where the students gve more comments on language changes than the contents.

Students in experimental group, when reviewing their peers' individual writing drafts, were asked to provide comments for at least three pieces of work from the peers uploaded in the Facebook group for their class. To enhance the students' awareness of the macro aspects of revisions such as content and organization, a training practice and explicit instructions for the number of responses in these two areas were given during the treatment (See Choi, 2014). The training practice was done during the classroom process through class discussion between teachers and students on what the students 
needed to provide while reviewing their peers' work.

Once the students received comments and feedbacks from their peers, they were required to revise and edit their work. At the end of the revision session, they were given a week to continue commenting on their peers' drafts and post their comments in Facebook. Every student writer could then access peer comments and revise his or her draft based on the useful comments. The revised draft (namely final draft) was then submitted online to the Facebook. At last, the teacher graded their final draft based on the writing content, organization, language use, vocabulary, and mechanics.

The reason why the increase of writing ability happened significantly in experimental group might be due to the fact that online peer feedback provided constructive and useful comments in the peer feedback of the individual tasks even though some of the students did not write the feedbacks in an organized, structural and comprehensive manner. Some of the students still gave surface-level review in terms of mechanics, and grammatical aspect. But it seems that these processes had made the students more aware about their errors or mistakes in writing. On the other hand, several students were able to make comments related to the ideas and organization of the paper.

Even though the increase occurs in the experimental group, the other factors such as the teacher's instruction and guidance through online learning via Facebook group might play a significant role in improving the students' writing ability (Kabilan et al, 2013). A small portion of teacher's feedbacks were also given in non-classroom learning. The students might be helped by the teacher's expertise and judgement in various ways to solve the assignment and 
difficulties that the students encountered during the lesson (See Guasch et al, 2013).

Some limitations were also noted in the present study in which the increase of each aspects of writing was not taken much attention. Further investigation towards the impact of online peer feedback on the writing aspects such content, organization, vocabulary, language use, and mechanics might be very important to find out to what extent online peer feedback might bring positive impact on the students' mastery of

EFL writing.

\section{CONCLUSION}

The present study might bring some light to the research on EFL writing. The role of technology in higher education has significantly changed the way EFL teaching and learning are carried out. Online peer feedback might be one of the alternatives to support the practice of teaching EFL writing at tertiary level. The utility of
Facebook that has gained abundant users for the last decade can be a useful media to facilitate non-classroom learning as to solve time constraints often encountered by some English teachers in Indonesia.

Further study might use larger sample to confirm the transferability of the effect of online peer feedback on EFL writing. Exploring the impact of more popular and usable social networks on the EFL writing might be very interesting since they might be very helpful for EFL teachers to engage the $21^{\text {st }}$ century learners in the learning process.

\section{ACKNOWLEDGEMENTS}

Many thanks are given to Ministry of research and higher of education who have given a research grant so that the present study can be carried out. Credit also goes to Universitas Teknokrat Indonesia particularly, English Literature Department that authorized the writer to conduct the research in the second semester of 2016/2017 academic year.

BAHTERA : Jurnal Pendidikan Bahasa dan Sastra, Volume Januari 2018 


\section{REFERENCES}

Al-Badwawi, H. S. Q. 2011. The Perceptions and Practices of First Year Students' Academic Writing at the Colleges of Applied Sciences in Oman. Oman: University of Leeds (Doctoral Dissertation).

Al-Ghazali, F. (2015). Peer feedback for peer learning and sharing. Learning and Teaching in Higher Education:

Gulf Perspectives, 12(1). http://the.zu.ac.ae

Aunurrahman, A., Hamied, F. A. \& Emilia, E. (2017). Modeling Academic Writing for University Students. Advances in Social Science, Education and Humanities Research (ASSEHR), vol 82. Paper presented in International Conference on Applied Linguistics (CONAPLIN 9). Atlantis Press.

Budiardi, A. C. and Anggraeni, B. 2013.

Facebook Base Writing Learning for Teaching English as a Foreign Language. International Journal on Education, Vol. 1, No. 1.

Choi, J. 2014. Online Peer Discourse in a Writing Classroom. International Journal of Teaching and Learning in Higher Education, Vol. 26 (2). pp.217231.
Choo, Ng Kui. 2001. The Case of Comprehensible Input in Teaching and Learning the Write Stuff. Proceedings of the FIFTH MELTA Biennial International Conference Petaling Jaya, Malaysia, Vol. 5, pp. 11-21.

Coffin, C. (2004). Arguing about how the world is or how the world should be: the role of argument in IELTS tests. Journal of English for Academic Purposes, 3(3), 229-246. http://doi.org/10.1016/j.jeap.2003.11.002

Falchikov, N. (2001). Learning together: peer tutoring in higher education. London: Routledge Falmer.

Kabilan, M. K., Ahmad, N., Abidin, M. J. Z. 2010. Facebook: An Online Environment for Learning of English in Institutions of Higher Education. Internet and Higher Education, Vol. 13, pp. 179-187.

Klucevsek, K. (2016). Transferring skills from classroom to professional writing: Student faculty peer review as an extension of cognitive apprenticeship. Journal of the Scholarship of Teaching and Learning, Vol. 16 (6), pp. 106-123. doi: $10.14434 /$ josotl.v16i6.20077 
Kroll, B. (2001). Considerations for teaching an ESL/EFL

writing course. In M. Celce-Murcia (Ed.),Teaching

English as a second or foreign language (3rd ed., pp.

219-232). Boston, MA: Heinle \& Heinle.

Low, P. \& Warawudhi, R. (2016). Undergraduates' Attitudes toward the Use of Facebook in Fundamental English Course. International Journal of Information and Education Technology, Vol. 6 (12). P 934-938

Martin, J. R. (2006). Mentoring semogenesis: "Genrebased" literacy pedagogy. In F. Christie (Ed.),Pedagogy and the Shaping of Consciousness:

Linguistic and Social Processes (pp. 123-155).

London, UK: Continuum.

Razak, N. A. and Saeed, M. A. (2014). Collaborative writing revision process among learners of English as a foreign language (EFL) in an online community of practice (CoP). Australasian Journal of Educational Technology, 30(5), pp.580-599.
Rollinson, P. (2005). Using peer feedback in the ESL writing class. ELT Journal, 59(1), 23-30. doi:10.1093/elt/cci003

Suthiwartnarueput, T. and Wasanasomsithi, P. 2012. Effects of Using Facebook as a Medium for Discussions of English Grammar and Writing of LowIntermediate EFL Students. Electronic Journal of Foreign Language Teaching, Vol. 9 (2), pp. 194-214.

Guasch, T., Espasa, A., Alvarez, I.M., \& Kirschner, P. A. (2013). Effects of feedback on collaborative writing in an online learning environment, Distance Education, 34 (3), pp. 324 - 338, DOI: 10.1080/01587919.2013.835772

Yang, Y.-F., \& Meng, W.-T. (2013). The effects of online feedback on students' text revision. Language Learning \& Technology, 17(2), 220-238. Retrieved from

http://llt.msu.edu/issues/june2013/yangm eng.pdf

Yunus, M. M. and Salehi, H. 2012. The Effectiveness of Facebook Groups on Teaching and Improving Writing: Students' Perceptions. International Journal of Education and Information Technology, Vol. 6, (1). 